\section{Synthesis and photochemical reactivity of caged glutamates with a $\pi$-extended coumarin chromophore as a photolabile protecting group}

\author{
Yuya Sakamoto ${ }^{\mathrm{a}}$, Srikanth Boinapally ${ }^{\mathrm{a}, \mathrm{b}}$, Claudine \\ $\mathrm{Katan}^{\mathrm{c}}$, and Manabu Abe $\mathrm{a}^{\mathrm{a}, \mathrm{b}, \mathrm{d}^{*}}$
}

a Department of Chemistry, Graduate School of Science, Hiroshima University (HIRODAI), 1-3-1 Kagamiyama, Higashi-Hiroshima, Hiroshima 739-8526, Japan, Tel: +81 82424 7432; fax: +81 424 7432, E-mail: mabe@hiroshima-u.ac.jp

${ }^{b}$ JST-CREST, Gobancho 7 K's Gabancho, Chiyodaku, Tokyo 102-0075, Japan

${ }^{c}$ CNRS, Institut des Sciences Chimiques de Rennes, UMR 6226, 35042

Rennes, France

${ }^{d}$ Institute for Molecular Science (IMS), Myoudaiji, Okazaki, Aichi 444-8787, Japan

\section{ABSTRACT}

"Caging" and "uncaging" bioactive substrates are key techniques in studying a wide variety of biological processes. In the present study, two-types of novel caged glutamates with a two-photon absorption (TPA) core, i.e. $\pi$-extended coumarin, were synthesized and their photochemical release of glutamate was analyzed. The high yields of glutamate $(>92 \%)$ were observed in the photolysis of compounds 1 and 10, respectively.

\section{Introduction}

"Caging" bioactive substrates (protection) and "uncaging" them under photolysis conditions (deprotection) are key techniques in studying a great variety of biological processes (Fig. 1). ${ }^{1}$ Glutamate (glu, $\mathrm{CO}_{2}^{-}\left(\mathrm{CH}_{2}\right)_{2} \mathrm{CH}\left(\mathrm{NH}_{2}\right)\left(\mathrm{CO}_{2}{ }^{-}\right)$) is known to be an important neurotransmitter that plays a key role for learning and memory. ${ }^{2}$ Several caged glutamates have been so far synthesized and used for physiological studies. Uncaging (photoreleasing) glutamate using two-photon (TP) excitation process is a most recent challenging subject in this field. ${ }^{3}$ The advantage of the TP excitation process includes the following two points: ${ }^{4}$ (1) the reduced scattering of the near IR photons in biological tissues gives an increase in depth compared with UV (one-photon: OP) excitation, and (2) TP excitation gives better definition of the focal spot than OP excitation. Thus, appropriate molecular design of chromophores is crucial in studying the role of the bioactive compound. Molecular design, synthesis, and photochemical reactivity of new caged compounds are of task for chemists.
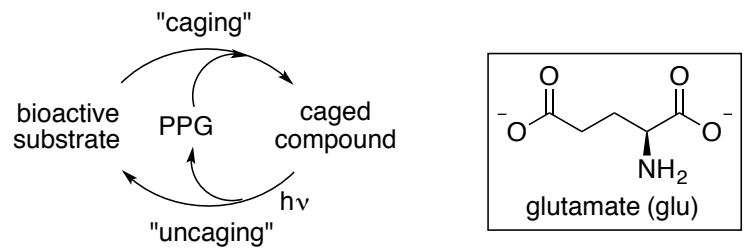

PPG: photo-labile protecting group

Figure 1. "Caging" and "uncaging" bioactive substrates.

Several chromophores for TP absorption (TPA) have been designed and synthesized in the last decade (Chart 1), e.g. bromohydroxycoumarin $(\mathrm{Bhc})^{5}$ core $\left(>1 \mathrm{GM}^{6}\right)$, 7-substituted coumarin derivatives ( 0.1-0.2 GM), nitroindolinyl (MNI, $\mathrm{CDNI})^{7}$ unit $(\sim 0.06 \mathrm{GM})$, nitrodibenzofuran $(\mathrm{NDBF})^{8}$ unit $(0.6$ $\mathrm{GM})$, 4-nitrobiphenyl unit $\left(\mathrm{PMNB}^{9}\right.$, up to $\left.11 \mathrm{GM}\right)$, and a quadrupolar structure of fluorine unit $(\mathrm{BNSF})^{10}$. In the present study, caged glutamates $\mathbf{1}$ and $\mathbf{2}$ with a $\pi$-extended coumarin core were designed and synthesized. Their photochemical release of glutamate was also conducted in this Letter. Photo-induced $\mathrm{S}_{\mathrm{N}} 1$ type of bond cleavage ${ }^{11}$ of $\mathrm{C}-$ glu was expected to release glutamic acid.

\section{Results and Discussion}

\subsection{Computational prediction of TPA}

First of all, the OP absorption (OPA) and TPA spectra of the parent chromophore unit 3 with a $\pi$-extended coumarin core were computed at the TD-B3LYP/6-31+G(d) level of theory in vacuum. ${ }^{12}$ Actually, $15 \mathrm{GM}$ was calculated for the first TPA maximum at $680 \mathrm{~nm}$ (Figure 2). This first peak shows a good correspondence with twice the wavelength of the first OPA band as was found for related chromophores. ${ }^{13}$ Environmental effects are expected to lead to both sizeable increase and red-shift of both OPA and TPA bands. Indeed, similar structure 4 was found to be $57 \mathrm{GM}$ at $750 \mathrm{~nm}$ in EtOH/buffer. ${ }^{14}$ The computed TPA

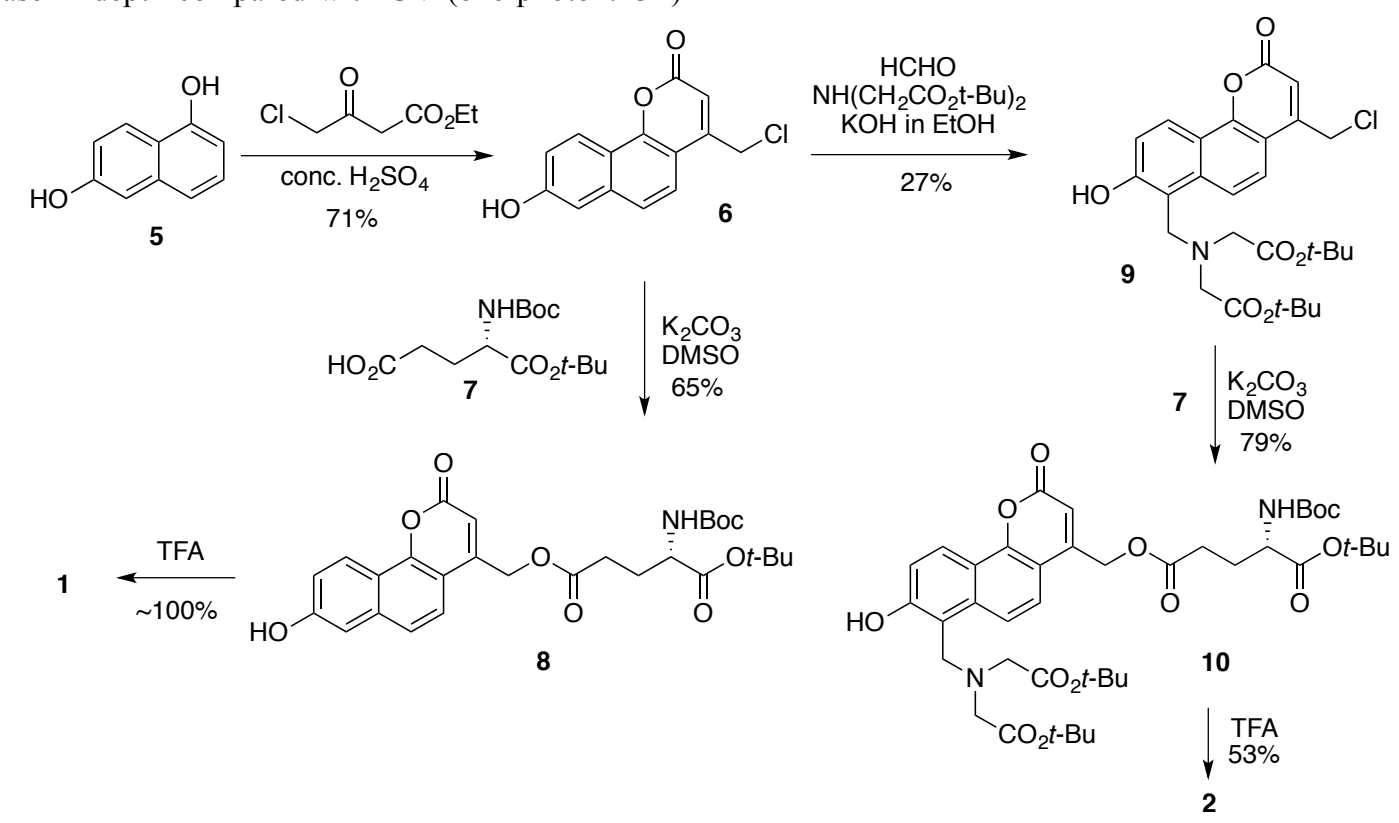

Scheme 1. Synthesis of caged glutamates $\mathbf{1}$ and 2 . 
<smiles>[Y]c1cc([N+](=O)[O-])c2c(c1[Y])CCN2</smiles>

$\mathrm{NI}, \mathrm{MNI}, \mathrm{CDNI}$<smiles>CC(C)C(C)(C)c1cc(-c2ccc([18OH])cc2)ccc1[N+](=O)[O-]</smiles>

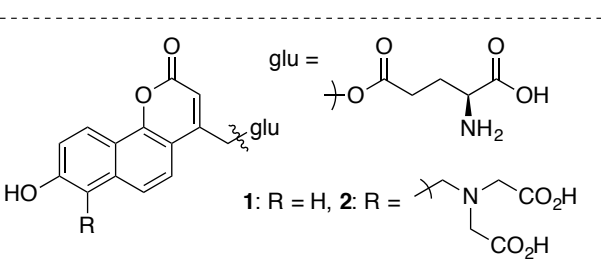

Chart 1. TPA chromophores.

spectrum of $\mathbf{3}$ with a sizeable TPA cross section (GM) prompted us to synthesize the caged-glutamates 1,2 and the photochemical reactivity was investigated.<smiles>Cc1cc(=O)oc2c1ccc1cc(O)ccc12</smiles>

3<smiles>COc1ccc2c(ccc3cc(C(=O)NCCN(C)C)c(=O)oc32)c1</smiles>

\section{2. "Caging” of Glutamate, Synthesis of 1 and $\mathbf{2}$}

Caged glutamates $\mathbf{1}$ and $\mathbf{2}$ were synthesized from the commercially available naphthalene-1,6-diol (5), Scheme 1 . The condensation of $\mathbf{5}$ with ethyl 4-chloro3-oxobutanoate produced a $\pi$-extended coumarin derivative 6 in $71 \%$ isolated yield. Slow addition of conc. $\mathrm{H}_{2} \mathrm{SO}_{4}$ at $0^{\circ} \mathrm{C}$, for ca. $30 \mathrm{~min}$, was found to be indispensable for obtaining 6 in high yields. The nucleophilic substitution reaction of $\mathbf{6}$ with protected glutamic acid $7^{15}$ gave the protected caged glutamate $\mathbf{8}$ in $65 \%$ isolated yield. The reaction conditions were tricky. The use of 0.5 equivalent of $\mathrm{K}_{2} \mathrm{CO}_{3}$ in dry DMSO was required for the high yield synthesis of $\mathbf{8}$. Other bases such as DBU and KF were found to be not appropriate for the substitution reaction. The caged glutamate $1\left(\lambda_{\max } 360 \mathrm{~nm}\right.$ in DMSO, $\varepsilon$ 9463) was obtained as TFA salts after deprotection of the Boc group and $t$-Bu group using trifluoroacetic acid (TFA). The compound 1 was thermally stable in methanol, thus, the study on the photochemical reactivity was possible. The results are shown in Figure 3, vide infra.

Water soluble group, i.e. $-\mathrm{N}\left(\mathrm{CH}_{2} \mathrm{CO}_{2} \mathrm{H}\right)_{2},{ }^{11 \mathrm{~d}}$ was introduced at $\mathrm{C}(7)$ position of $\mathbf{6}$ to give compound $\mathbf{9}$. The water solubility is necessary for the biological test. After the introduction of the glutamate unit 7 and the deprotection of $\mathbf{1 0}$ gave compound 2 (1.9 mM watersolubility in $\mathrm{pH} 7.4$ HEPES buffer, $\lambda_{\max } 362 \mathrm{~nm}$ in DMSO, $\varepsilon$ 9854). Although the protected glutamate
10 was stable in methanol solution, the deprotected compound $\mathbf{2}$ was slowly decomposed in water and methanol. Thus, the chemical yield of $\mathbf{2}$ was tentative. The photochemical release of glutamate derivative was tested in the photolysis of compound $\mathbf{1 0}$ (Figure 4 , vide infra).

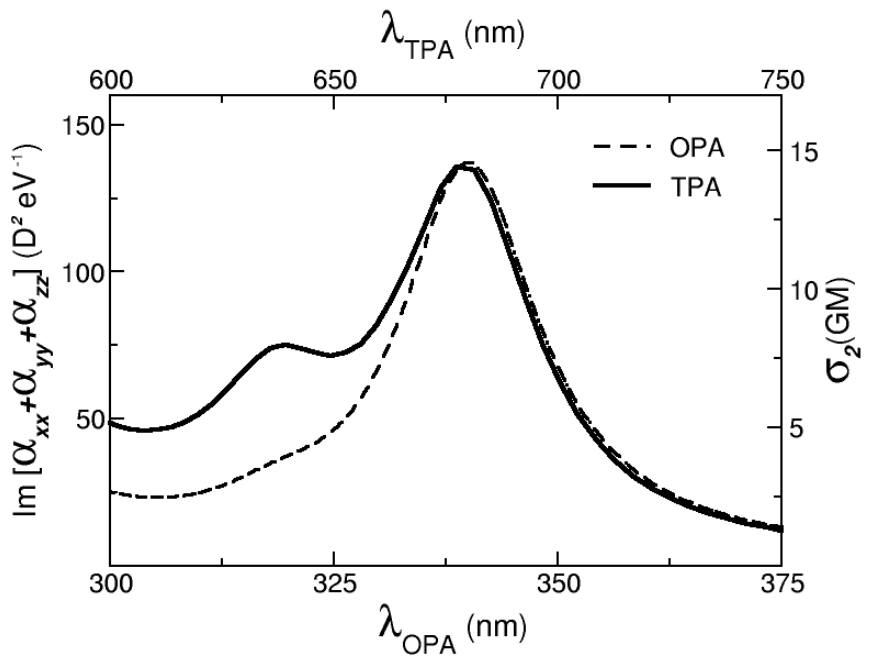

Figure 2 Calculated OPA (dashed lines) and TPA (lines) spectra of compound 3 in vacuum at TD-B3LYP/6-31+G(d) level of theory.

\section{3. "Uncaging” of Glutamate, Photochemical Reaction of $\mathbf{1}$ and $\mathbf{1 0}$}

Photochemical release of glutamic acid ("uncaging") from compound 1 (35 umol) was conducted in $\mathrm{CD}_{3} \mathrm{OD}(2.5 \mathrm{~mL})$ through a Pyrex filter using high-pressure $\mathrm{Hg}$ lamp (> $290 \mathrm{~nm})$, Figure 3). The photochemical reaction was monitored using ${ }^{1} \mathrm{H}$ NMR (400 MHz) spectroscopic analysis. As shown in Figures $3 a-c$, the release of glutamic acid ("uncaging") was clearly observed. The quantitative uncaging of glutamic acid at $60 \%$ conversion of 1 was proved by comparing the ${ }^{1} \mathrm{H}$ NMR spectrum (Figure $3 \mathrm{c}$ ) with that of the authentic sample (Figure 3d). The photoinduced $\mathrm{S}_{\mathrm{N}} 1$ type of the $\mathrm{C}-\mathrm{O}$ bond cleavage ${ }^{11}$ was proposed for the mechanism of the photochemical release of glutamic acid. The quantum yield of for the formation of glutamic acid from $1\left(\varepsilon_{355}=10634\right)$ was determined to be 0.006 at $355 \mathrm{~nm}$ irradiation using Nd: YAG laser $(10 \mathrm{~Hz}, \sim 7 \mathrm{mg}, 4-5 \mathrm{~ns}$ pulse-width). The photochemical formation of acetophenone $(\Phi=$ 0.33 ) from valerophenone was used as a chemical actinometer reaction. ${ }^{16}$ Thus, $\varepsilon_{355} \mathrm{x} \Phi$ value was calculated to be 63.8. Although the formation of the glutamic acid was clearly observed in the photolysate, white precipitation was detected during the photolysis. The white precipitate is supposed to be the products from the coumarin part. But, the structure was not determined because of the broadening of the ${ }^{1} \mathrm{H}$ NMR spectrum. 


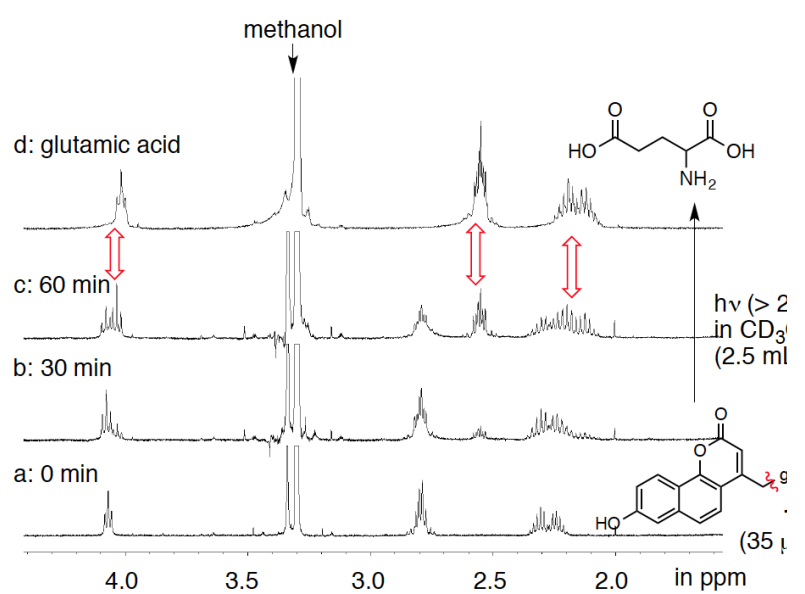

Figure 3. (a) ${ }^{1} \mathrm{H}$ NMR of caged glutamate 1 in $\mathrm{CD}_{3} \mathrm{OD}$; (b) ${ }^{1} \mathrm{H}$ NMR spectrum after 30 min irradiation of 1 using high-pressure Hg lamp through a Pyrex filter; (c) ${ }^{1} \mathrm{H}$ NMR spectrum after 60 min irradiation of $\mathbf{1}$; (d) $1 \mathrm{H}$ NMR spectrum of glutamic acid (TFA salt) in $\mathrm{CD}_{3} \mathrm{OD}$.

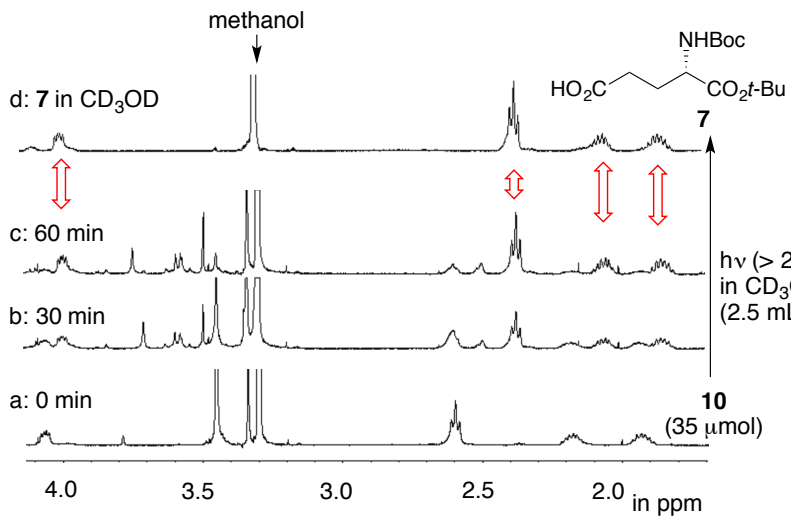

Figure 4. (a) ${ }^{1} \mathrm{H}$ NMR of caged glutamate 10 in $\mathrm{CD}_{3} \mathrm{OD}$; (b) ${ }^{1} \mathrm{H}$ NMR spectrum after $30 \mathrm{~min}$ irradiation of $\mathbf{1 0}$ using highpressure Hg lamp through a Pyrex filter; (c) ${ }^{1} \mathrm{H}$ NMR spectrum after 60 min irradiation of 10; (d) $1 \mathrm{H}$ NMR spectrum of 7 in $\mathrm{CD}_{3} \mathrm{OD}$.

The release of the glutamate unit was also tested in the photolysis of compound $\mathbf{1 0}$ under the similar conditions for compound 1 (Figure 4). The clean formation of protected glutamate 7 was observed in the photolysate of $\mathbf{1 0}$ after $60 \mathrm{~min}$, compare Figure 4c with Figure 4d. The chemical yield of compound 7 was determined to be $92 \%$ using $\mathrm{Ph}_{3} \mathrm{CH}$ as an internal standard. The quantum yield for the formation of 7 from $10\left(\varepsilon_{355}=8741, \varepsilon_{355} \Phi=96.2\right)$ was determined to be 0.011 using the similar method determined for $\mathbf{1}$.

\section{Summary}

New types of caged-glutamates with sizable TPA core were designed and synthesized with good chemical yields. The photochemical reaction was proved to release glutamic acids in high yields. Femtosecond laser system is necessary to test the TP excitation reaction. In the present study, the OP excitation was investigated to see whether glutamate was released under photolysis conditions.

\section{Acknowledgments}

NMR and MS measurements were performed at NBARD, Hiroshima University. This work was partially supported by a Grant-in-Aid for Science Research on Innovative Areas "Stimuli-responsive Chemical Species" (No. 24109008), "pi-Space” (No. 21108516), and No. 19350021 from the Ministry of Education, Culture, Sports, Science and Technology, Japan, and by the Tokuyama Science Foundation.

\section{References and notes}

1. (a) Ellis-Davies, G. C.R. Beilstein J. Org. Chem. 2013, 9, 64-73. (b) Klán, P.; Solomek, T.; Bochet, C. G.; Blanc, A.; Givens, R.; Rubina, M.; Popik, V.; Kostikov, A.; Wirz, J. Chem. Rev. 2013, 113, 119-191.

2. For example: (a) Parpura, V.; Basarsky, T. A.; Liu, F.; Jeftinija, K.; Jeftinija, S.; Haydon, P. G. Nature, 1994, 369, 744-747. (b) Matsuzaki, M.; Hayama, T.; Kasai, H.; EllisDavies, G. C. R. Nature Chem. Bio. 2010, 6, 255-257.

3. Bort, G.; Gallavardin, T.; Ogden, D.; Dalko, P. I. Angew. Chem. Int. Ed. 2013, 52, 4526-4537.

4. Pawlicki, M.; Collins, H. A.; Denning, R. G.; Anderson, H. L. Angew. Chem. Int. Ed. 2009, 48, 3244-3266.

5. (a) Givens, R. S.; Rubina, M.; Wirz, J. Photochem. Photobiol. Sci. 2012, 11, 472 - 488. (b) Furuta, T.; Wang, S. S. H.; Dantzker, J. L.; Dore, T. M.; Bybee, W. J.; Callaway, E. M.; Denk, W.; Tsien, R. Y. Proc. Natl. Acad. Sci. USA 1999, 96, 1193-1200

6. Göppert-Mayer (GM) unit: $1 \mathrm{GM}=10^{-50} \mathrm{~cm}^{4} \mathrm{~s}$ photons ${ }^{-1}$ molecule $^{-1}$; named in honor of Maria Göppert-Mayer, who set the theoretical basis of the TPA process, see: (a) Gçppert-Mayer, M. Ann. Phys. 1931, 401, 273-294.

7. (a) Papageorgiou, G.; Ogden, D. C.; Barth, A.; Corrie, J. E. T. J. Am. Chem. Soc. 1999, 121, 6503-6504. (b) Morrison, J.; Wan, P.; Corrie, J. E. T.; Papageorgiou, G.; Photochem. Photobiol. Sci. 2002, 1, 960-969. (c) Papageorgiou, G.; Corrie, J. E. T. Tetrahedron 2000, 56, 8197-8205. (d) Canepari, M.; Nelson, L.; Papageorgiou, G.; Corrie, J. E. T. Ogden, D. J. Neurosci. Methods, 2001, 112, 29-42. (e) Trigo, F. F.; Papageorgiou, G.; Corrie, J. E. T.; Ogden,D. J. Neurosci. Methods 2009, 181, 159-169. (f) Papageorgiou, G.; Beato, M.; Ogden, D. Tetrahedron 2011, 67, 5228-5234. (g) Gasparini, S.; Magee, J. C. J. Neurosci. 2006, 26, 20882100. Losonczy, A.; Magee, J. C. Neuron 2006, 50, 291307. (h) Nikolenko, V.; Poskanzer, K. E.; Yuste, R. Nat. Methods 2007, 4, 943-950. (i) Matsuzaki, M.; Ellis-Davies, G. C. R.; Kasai, H. J. Neurophysiol. 2008, 99, 1535-1544. (j) Fedoryak, O. D.; Sul, J.-Y.; Haydon, P. G.; Ellis-Davies, G. C. R. Chem. Commun. 2005, 3664-3666. (k) Papageorgiou, G.; Ogden, D.; Kelly, G.; Corrie, J. E. T. Photochem. Photobiol. Sci. 2005, 4, 887-896. (1) EllisDavies, G. C. R.; Matsuzaki, M.; Paukert, M.; Kasai, H.; Bergles, D. E. J. Neurosci. 2007, 27, 6601-6604. (m) Papageorgiou, G.; Lukeman, M.; Wan, P.; Corrie, J. E. T. Photochem. Photobiol. Sci. 2004, 3, 366-373. (n) Papageorgiou, G.; Ogden, D.; Corrie, J. E. T. J. Org. Chem. 2004, 69, 7228-7233.

8. Momotake, A.; Lindegger, N.; Niggli, E.; Barsotti, R. J.; Ellis-Davies, G. C. R. Nat. Methods 2006, 3, 35-40.

9. Donato, L.; Mourot, A.; Davenport, C. M.; Herbivo, C.; Wather, D.; Léonard, J.; Bolze, F.; Nicoud, J.-F.; Kramer, R. H.; Boeldner, M.; Specht, A. Angew. Chem. Int. Ed. 2012, $51,1840-1843$

10. Gug, S.; Charon, S.; Specht, A.; Alarcon, K.; Ogden, D.; Zietz, B.; Leonard, J.; Haacke, S.; Bolze, F.; Nicoud, J.-F.; Goeldner, M. ChemBioChem. 2008, 9, 1303-1307. 
11. (a) Bartrop, J. A.; Schofield, P. Tetrahedron Lett. 1962, 3, 1138-1141. (b) Chamberlin, J. W. J. Org. Chem. 1966, 31, 1658-1660. (c) Zimmerman, H. E.; Sandel, V. R. J. Am. Chem. Soc. 1963, 85, 915-922. (d) Hagen, V.; Kilic, F.; Schaal, J.; Dekowski, B.; Schmidt, R.; Kotzur, N. J. Org. Chem. 2010, 75, 2790-2797.

12. (a) Becke, A. D. J. Chem. Phys. 1993, 98, 5648. (b) Lee, C.; Yang, W.; Parr, R. G. Phys. Rev. B 1988, 37, 785.

13. Makarov, N. S.; Drobizhev, M.; Rebane, A. Optics Express 2008, 16, 4029-4047

14. Son, J. H.; Lim, C. S.; Han, J. H.; Danish, I. A.; Kim, H. M.; Cho, B. R. J. Org. Chem. 2011, 76, 8113-8116.

15. More, S. S.; Vince, R. J. Med. Chem. 2009, 52, 4650-4656.

16. Wagner, P. J.; Kemppainen, A. E. J. Am. Chem. Soc. 1968, $90,5896$.

\section{Supplementary Material}

Computational details, experimental section including ${ }^{1} \mathrm{H}$ and ${ }^{13} \mathrm{C}$ NMR for all new compounds $\mathbf{1}$, 8, 9, 10 . 